\title{
Resilience in urban development projects in flood-prone areas: a challenge to urban design professionals
}

This article analyses how more resilient cities can be built in flood-prone areas by looking at the various ways urban design professionals get involved in urban development projects. While stressing the aesthetic values added by water environments, urban professionals (i.e. urban designers, landscape designers and architects) also have to deal with a number of risks specific to waterways and floodprone areas. They also find themselves facing a range of operational difficulties that can be solved either at the immediate building level or at the area level. This study focuses on four French projects developed in three medium-sized cities, Le Havre, Angers and Narbonne, as well as in a small city, Romorantin. Leveraging those examples, it provides an opportunity to better understand how vulnerability and resilience are dealt with by urban design professionals, as well as how the latter attempt to articulate the various and sometimes conflicting aspects of their projects - should they be political, æsthetic, technical or urban. This article will focus more specifically on architectural and urban forms. It will review some of the limits they present in terms of risk management, when reducing vulnerability to flooding becomes the number one priority.

Keywords: urban development project, vulnerability, flood risk, flood-prone area, city professionals, resilient urban design

\section{Introduction}

Will it ever be possible to see urban projects in flood-prone areas that integrate flood risks as a key element of the whole development process? In February 2010, the famous Storm Xynthia hit continental France. However, several years later, the various ways for the authorities and developers to control urbanisation and adapt architecture in those areas are still a burning issue. Indeed, state authorities do prohibit buildings in the most exposed territories, as outlined in flood-risk prevention plans. However, they are still striving to ensure that risk assessment strategies are duly implemented in lowor moderate-hazard flood-prone areas that remain constructible.

In such locations, developers must consider various residential and commercial issues - not to mention the multiple constraints pertaining to any development project. At the same time, they also have to make sure they do not increase flood exposure either locally or at the level of the overall urban system. However, according to a set of arguments developed by 'resilient urban planning' groups (Liao, 2012; Barroca and Serre, 2012; Barroca and Hubert, 2008), neighbourhood experts' techniques and knowhow could be harnessed to great benefit in the very process of urban design, in order to better assess the risks, reduce vulnerability and enhance resilience. Were this strong potential to be tapped, urban systems would not be so exposed to flood events and their damage would tend to be limited.

In the following pages, we will examine how resilience proves operational at the scale of urban development projects. By looking at how various project designs are applied to urban planning projects 
in the four flood-prone areas we have selected - Le Havre, Angers, Narbonne and Romorantin - this article reflects on how urban design tends to evolve towards the construction of more flood-resilient cities, and how the various professionals involved in the process turn out to integrate flood risks into

their work. Indeed, urban design appears in many ways as 'the melting pot where ambitions, knowledge and practical experiences come together to deliver flood-resilient developments' (Zevenbergen, 2010, 46). The aim of this article is therefore to understand how urban design professionals who value the proximity of water as an asset also happen to deal with the risks associated with it, and how they integrate those risks at the different levels of their projects.

In order to do so, we have conducted an extensive review of the ways in which urban design professionals tend to integrate flood-risk prevention into their work. As it appears, resilient approaches applied to floods in urban settings raise major issues, not only in terms of flood-risk management but also in terms of spatial quality in the built environment (Nillesen and Kok, 2015).

This article will therefore try and answer the two following research questions: how do professionals manage to integrate flood risks for projects located in floodprone areas? Simultaneously, how do they manage to overcome the difficulties raised by this type of urban development, and how does this translate specifically at each step of the development process? What kind of urban forms does this generate? While reviewing these questions, we will also try and point out how the solutions that urban design professionals come up with sometimes appear to be limited answers to the complex challenges posed by flood-risk reduction, especially when applied to new or remodelled neighbourhoods. In order to answer these questions, this article will build on some of the results provided by PRECIEU ${ }^{1}$, a research project looking at how changes in urban design professions and in the making of cities, happen to impact project development. While doing so, this research project tries to assess more specifically the various uncertainties and constraints linked to flood risks and to the set of regulations associated with it.

The set of theoretical data on urban projects and urban resilience used for this article is drawn from a state-of-the-art section drafted for the PRECIEU project. In addition to that, bibliographical enrichment from English literature allows us to compare how urban design professionals deal with flooding in France and in other countries. Moreover, empirical data from our four case studies have been collected in the field, including a series of semi-structured interviews conducted with key stakeholders, as well as an analysis of urban planning materials.

We first give an outline of our research design and methodology, before providing a quick overview of the French regulatory context applicable to flood risks and urban development in flood-prone areas. We then review some of the various urban and architectural forms that were produced as a result of measures mitigating flood risks, whilst examining the potential for innovation linked to it. We then extend the scope of our analysis, going beyond existing legislation to look at some of the strategies that are now implemented at the scale of city blocks and individual buildings. The final section presents some of the technical difficulties raised by this broader form of floodrisk mitigation. In conclusion, we discuss some of the limits encountered by these approaches in terms of urban design and resilience to floods.

\footnotetext{
${ }^{1}$ Study programme conducted on the constraints of flooding in urban projects in flood-prone areas. Financed by the French Ministry of Ecology, Sustainable Development and Energy. This study programme was directed by Mathilde Gralepois (University of Tours) and Sylvain Rode (University of Perpignan).
} 


\section{Research design: underlying assumptions}

Focused on the specific constraints generated by flooding in urban projects in floodprone areas, PRECIEU is a research programme looking at how flood risks are integrated in urban projects at the neighbourhood scale. As it appears, several French cities have chosen to undertake urban development projects in flood-prone areas where new constructions are possible, but strictly controlled by regulations. The PRECIEU programme therefore aims at examining urban design professionals' practices, and how they deal with urban development projects in these specific contexts. What are the ways flooding constraints find themselves defined or diluted by professionals throughout the various project phases? To answer this question, PRECIEU considers the urban project context as the current way of building cities and of 'widening the scope of possibilities' (Hubert, 2014, 226), as well as an opportunity to build cities with water (Ryan, 2010).

Hypothesis 1: the project way of building - a new understanding for designing cities in flood-prone areas

Urbanism by project has often been presented by French specialised literature as a better and more appropriate way of building cities. This kind of urbanism is opposed to a regulated form of urban development relying on rigid sets of rules (Atelier Castro Denissof Casi and Nexity, 2011). Several authors (Ingallina, 2008; Novarina, 2003) consider that such ways of building cities drawn from project management are more flexible and innovative, but also that they are more prone to accommodate the specificities of each territory in risky areas.

The 'project way' of building is indeed seen by urban professionals as preferable to prohibitive regulations such as flood-risk prevention plans (Bonnet, 2016). Promoted by the European Union, such normative instruments have forced the authorities and city planners to build under very strict rules for the sake of flood-risk mitigation. For example, buildings have to be over the highest-known fluvial and coastal flooding tides observed over the past 100 years in order to minimise the threat of exceptional millennial floods.

Moreover, in some areas, new buildings were banned in order to prevent flood-risk losses. As reported many times in French specialised literature (Atelier Castro Denissof Casi and Nexity, 2011; Beurier, 2011; Lesquel, 2010; Dégardin and Gaide, 1999), these normative frames are deemed restrictive and absurd by many urban design professionals. The latter would rather defend resilient design approaches presented as being less limiting and more flexible when it comes to dealing with flood risks' changing dynamics (Antrobus, 2010; Liao, 2012; Van Veelen, 2016). Many of them see these rules as arbitrarily imposed by the state, without any concern as to whether or not they are actually relevant to local contexts.

Furthermore, such regulations are thought to discourage such innovative responses as those witnessed in Hamburg or Frankfurt, for example, where every element of the risk context was fully taken into account. Although funding streams tend to vary much from one city to another, many voices can be found in international journals which criticise flood-risk constraints and the way they force cities to compete at a European or even global level: 'In France, we are subjected to non aedificandi areas, while our neighbours build everywhere' (Beurier, 2011, 34, quoting the Architect Yves Lion in 2011). However, similar debates about flood management can be observed far beyond French boundaries. In England, for instance, in the 1990s, public concerns about flood effects encouraged the adoption of a more prohibitive approach. For this reason, floodplain regeneration projects such as the Lower Broughton project in central Salford became very controversial (Antrobus, 2010). 
As its defenders argue, urbanism by project provides an opportunity to bring together engineers, architects, land surveyors, hydraulic engineers, urban designers and landscape designers, among others. It makes them work together in interdisciplinary teams, enabling them to address flood-risk problems in a better and more innovative way. The idea is that architects' and engineers' creative skills can, when combined, come up with alternative solutions in both social and technical terms. Interestingly, the same arguments in favour of more flexible action frames are pushed forward by the advocates of resilience-based flood management (Watson and Adams, 2010; Liao, 2012; Van Veelen, 2016). The latter defend a much more adaptive approach in tune with the changing environments in which they operate. In addition, according to urban-project methodology, actions are to be undertaken at several scales of regional and local government, using an iterative process until project completion.

From this perspective, any given urban project has thus to be approached in riskprone areas as an alternative to standard construction programmes - bearing in mind that a special board of experts ensures that relevant risks are duly addressed and that requirements are complied with on the social, political and technical fronts (Bonnet, 2016).

Yet it remains to be seen whether this discourse can actually pass the test of practice. This particularly requires urban professionals to be willing to step outside their field of expertise and pay careful attention to the viewpoints of their colleagues coming from other disciplines. What are, then, the most efficient ways for urban professionals to make decisions when responding to a given risk context? How do these decisions happen to take shape in the urban environment?

This being said, rules and projects should not simply be opposed. If urbanism by project in the field of resilient urban planning is increasingly considered in the scientific literature as both 'widening the scope of possibilities' (Hubert, 2014, 226) and able to better integrate risks in urban design, the project management perspective does not make rules irrelevant either.

It rather seems like opening up a dedicated time frame and space to negotiate the rules specific to each project. Therefore it does not contradict the fact that regulation, although adapted or even sometimes softened for the needs of a given project, remains omnipresent and has to be dealt with. This particularly makes sense if part of urban designers' remit is understood precisely as making sure that the various constraints of a territory are dealt with, synthesised and translated into urban and architectural forms. Viewing projects as spaces offering total freedom where the creativity of designers can be left unchecked appears to be nothing more than an illusion.

As a consequence, projects in flood-prone areas are necessarily framed by strong regulations. Nevertheless, the flexible and interactive rationale at the basis of the project way of building is deemed to foster an effective search for solutions, in tune with local contexts. It is also valued as favouring a good balance between risk prevention and urban development, unlike PPRs (natural risk prevention plans), sometimes seen as being part of a fussy and prohibitive logic.

Hypothesis 2: urban development projects as a relevant scale to understand operational choices in flood-risk prevention

Urbanism by project operates at several scales of action (Ingallina, 2008), articulating regional territories (also called global urban projects), cities (i.e. local urban projects), neighbourhoods (urban development projects), and buildings themselves (architectural projects) - the latter two proving the most operational. In order to better understand the difficulties encountered on the ground by urban professionals, the PRECIEU research programme focuses its perspective at the scale of the urban development project, with the aim of illustrating the different ways in which its underlying principles can turn into urban shapes (buildings) (Arab, 2007; Novarina, 2003). Therefore, this scale appears 
particularly relevant in terms of project design, but it is also particularly interesting to study the way in which projects get materialised.

The urban development projects that fall within the scope of this paper crystallise major issues in terms of urban development. Embedded within territorial contexts, (Ingallina, 2008; Arab, 2007) they are designed at the same time as 'pieces of a city'. They become as such the basis for development strategies at the level of the mediumsized cities in which they are located (Demazière, 2014; Nadou, 2010) such as Le Havre, Angers and Narbonne.

Focused on asserting themselves as urban poles at the regional scale, these cities' agendas are driven by the pursuit of growth, distinction and attractiveness. In this respect, urban planning projects and their reflections at the scale of the neighbourhood take on another dimension, as a very good way for cities to showcase their strategy and gain visibility.

However, in a context where the authorities devote more and more efforts to trying to rein in urban sprawl, limited potentials for property development open the way for the rehabilitation of floodplains. With historic city centres often built on riverbanks, these floodplains turn out to occupy central locations (Dégardin and Gaide, 1999; Dégardin, 2002; Lechner, 2006; Antrobus, 2010). The rationale is then to reclaim former brownfields and to restore the city in the city itself. When these plans do succeed, the proximity of water is viewed by the authorities as more of a development opportunity (Allaman, 2003; Watson and Adams, 2010) and less of an inconvenience. The attractive location of floodplains, their potential as saleable property and the symbolic power of visible water make them crucial elements of urban strategies (Verdelli and Morucci, 2014). This in turn has substantial impacts in terms of which constraints are deemed acceptable and which can be integrated at the operational level.

In the four cases we studied, the assets of flood-prone areas seem to outweigh their constraints. Waterfronts (rivers in Angers and Romorantin, a waterway in Narbonne and docks in Le Havre) appear as central features in an urban renewal discourse emphasising water and its many advantages in terms of living environment - whether they be natural, recreational, patrimonial or touristic. It is generally admitted that water is being given a new and more important place in urbanised spaces. As Zoé Ryan $(2010,7)$ writes, 'water has become central to discussions about new architecture and urban planning'. This new relationship with water and this change in the discourse about flooding brings about substantial changes in the way architects and urban designers deal with flood-prone areas and position themselves with regard to flood risks. For French architect Frédéric Bonnet (Great Town Planning Award in 2014), 'the notion of risk sparks a small revolution in the world of urban design' (Bonnet, $2016,13)$. In this new context, how do urban project professionals manage to innovate and build more resilient cities while not losing sight of other key urban concerns?

\section{A qualitative methodology: comparative analysis based on French case studies}

Our research aims at pointing out the way in which cities that do not have the same resources as international cities like Hamburg (and its well-known HafenCity development; Marie, 2014) or Mainz (with the Zollhafen development project; Webler, 2014) work to build a new image by resolving floodrisk difficulties in an urban project context. In order to do so, the PRECIEU programme focuses on urban development projects taking place in three French medium-sized cities (figure 1): Le Havre (with the Saint Nicolas development project), Angers (with the Thiers Boisnet and Saint-Serge neighbourhoods, as well as the with Angers rives nouvelles project) and Narbonne (with the Robine Riverbanks project). Our analyses also rely on a fourth case study based in Romorantin, a small city located in the centre of 
France. Interestingly, the Matra neighbourhood we are looking at in this town has been designed as a resilient district. Implemented on the site of a former industrial brownfield, it was flooded in June 2016, a very short time after its completion. A member of the PRECIEU research team, the architect in charge of the project, made sure the neighbourhood could contribute to the design process and take part in the integration of flood risks in the overall project. The research team assumes that combining state-of-the-art knowledge with the results of these four case studies provides a good basis to illustrate how global trends in resilient urban design practices happen to be implemented in the French context.

Figure 1. Four case studies in four medium-sized and small French cities

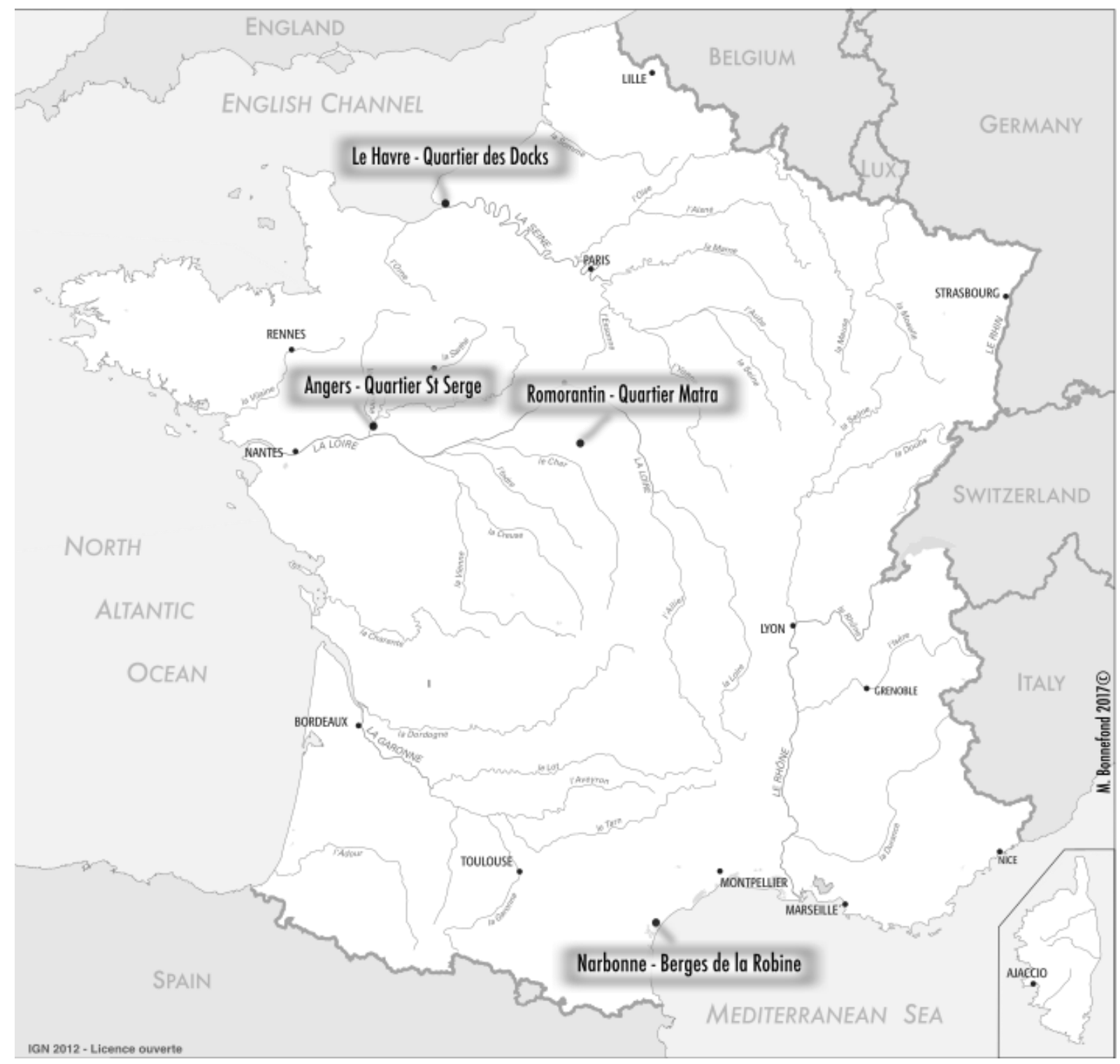

As mentioned previously, our main objective is to understand the way in which flood risks are integrated in resilient urban project dynamics. In order to reach this goal, the comparative analyses conducted by PRECIEU rely for each development project on a set of formal documents, including preliminary studies made at the conception stage. In addition, the PRECIEU team interviewed key players on each project, paying special attention to the urban professionals who were involved in their design: architects, landscape designers, urban designers, developers, political figures and project managers. In total, fifty semi-structured interviews were conducted between 2014 and 2016. The methodology also included on-site visits as well as the organisation of two scientific and technical 
expert committees (one in March 2015 and the other in June 2016) in order to review the research outputs and provide external feedback. Finally, a one-day seminar was held in October 2016 in Paris, the outcomes of which also form part of our data basis.

\section{Understanding the French regulatory context related to flood risk and urban development in flood- prone areas}

In France, urbanisation control in flood-prone areas is a state prerogative exercised under the provisions of the PPRs (natural risk prevention plans). Created in 1995 by the 'Barnier law' related to the reinforcement of environmental protection policies, these plans are designed by state services and have to be implemented by local authorities, the latter being responsible for urban development in their territory. PPRs identify flood-prone areas and also define land use rules that apply at every risk level and in local urban planning documents (PLUs - local urban plans).

In most cases, PPRs distinguish between 'red' and 'blue' areas. According to this colour code, red areas are exposed to high risk levels. As a result, new buildings are banned and urban development is no longer possible. In blue areas which are exposed to medium or low risk levels, new buildings are allowed but have to comply with specific rules and guidelines in order to be able to face flooding without incurring major damage. Such specifications include NGF altimeter levels below which construction is not permitted ${ }^{2}$, as well as rules regarding land use and the amount of maximum floor space allocated. These norms are established by state services according to the plus hautes eaux connues (PHEC - highest known flood level) ${ }^{3}$.

In the areas identified as 'blue' under the PPR colour code, urban development can go on. As a result, many French cities are currently carrying out new projects in flood-prone areas (Larrouy-Castera and Ourliac, 2004; Commissariat Général au Développement Durable, 2009). In Angers, Narbonne and Romorantin, the development projects we studied are located in areas subject to flood regulations. Each flood risk prevention plan (namely Confluence Maine in Angers, Rec du Veyret in Narbonne and Sauldre in Romorantin) impose special rules in terms of urban planning and construction, including land-use provisions as well as requirements relative to dredging/filling, floor heights, flood sensitive installations and equipment, and so on.

In the aftermath of Storm Xynthia, in February 2010, the French state decided to speed up the implementation of PPRs, particularly in coastline zones and in areas where human lives were at risk. By December 2012, according to the Observatoire national des risques naturels, 7,855 municipalities had set up effective flood-risk prevention plans, while 3,562 cities had drafted plans that were yet to be finalised. Out of the 36,611 municipalities of the French metropolitan territory, about a third are exposed to flood risk.

In the cities equipped with PPRs, this tool tends to moderate urban growth in flood-prone areas. The Commissariat général au développement durable observed, for example, in its 2010 environmental report that 'municipalities with pre-2005 prevention plans displayed less extensive forms of urbanisation in flood-prone areas for the years between 2000 and 2006' (Commissariat général au

\footnotetext{
${ }^{2}$ The Nivellement général de la France (Overall Levelling of France), known as IGN69, is an altitude system and the official vertical geographic reference for metropolitan France.

${ }^{3}$ Flooding higher than the PHEC can lead to an updating of the norm. After the flooding of the Maine in 1995, floor levels imposed on new construction were raised, as in the Saint-Serge and Thiers-Boisnet districts of Angers.
} 
développement durable, 2010). In fact, PPRs have made it possible to reduce construction footprints in floodprone areas, as witnessed, for instance, in the middle Loire valley (Rode, 2009).

However, the state's willingness to control land use is often locally perceived as an unacceptable constraint (Pigeon, 2007; Rode, 2009). Indeed, flood prevention policies tend to jeopardise plans in terms of economic and demographic development at the level of local authorities. 'In most satellite cities, the paradigm of elected officials remains that of population growth. It is a source of income as well as a source of power and influence' (Gaudillière, 2005, 62). For example, municipalities willing to develop coastal and riparian areas because of their appealing features do not approve of the restrictive regulation set imposed by PPRs (Carré, 2006; Beucher and Rode, 2009). They see it as a constraint threatening their capacity to fulfil the vision they have for the city. Putting a halt to many development projects and placing urban policies, as a whole, under substantial constraints, flood regulations cause significant conflict. Both municipalities and residents can convene in associations in order to oppose the state's preventive policies and alleviate regulatory pressures (Beucher and Rode, 2009). Many local politicians have tried to promote alternative zoning forms which would enable them to conduct the urban development projects standing at the top of their political agenda.

Therefore, if PPRs appear to be instruments that 'in principle ensure equality of treatment over the French territory' (Hubert, 2014, 220), reflecting the state's power over urbanisation control in floodprone areas, their implementation involves many negotiations between state services and local authorities (Rode, 2012; Moulin et al., 2013).

However, if the state does end up playing a major role, municipalities also have some level of flexibility to adapt national rules to local contexts, thus remaining key local actors for flood-risk management.

\section{Envisioning resilient cities: towards innovative architectural and urban forms in flood-prone areas?}

Studying urban projects in floodplains entails looking at how flood-risk regulation translates into concrete and potentially innovative urban forms. In order to safeguard residential areas in the territories exposed to submersion risk, professionals strive to comply with flood risk levels defined by land-use requirements ${ }^{4}$, either at the scale of buildings or at the level of a broader area. This generates specific urban forms which sometimes happen to be problematic and even counterintuitive in terms of both city life and risk management.

Among the projects we have studied, it appears that the issue of flood risk was largely ignored by planning professionals in the 1980s and 1990s. Largely underestimated during the planning and design stages, flood risks were only considered later on in the process, when projects had to be deemed compliant with a number of regulatory norms. More recently architects and urban designers tried to find ways to integrate flood constraints by adapting the buildings' architecture. This resulted in the emergence of unique urban forms, two examples of which can be found in Angers within the SaintSerge 1 and Thiers Boisnet neighbourhoods. Beyond their specificities, these two cases show that taking flood risk into account through norms can lead to unique urban forms, whose relevance can be questioned.

\section{Taking flood risk into account produces unique urban forms}

\footnotetext{
${ }^{4}$ Among other provisions, flood protection rules include several specific components worthy of note: standard minimum levels for new buildings defined on the basis of submersion height specifications (i.e. the highestknown waters), limits on the surface occupied by buildings and a need for floodways between buildings to facilitate water flow.
} 
Built in the 1990s, the Saint-Serge 1 and Thiers Boisnet districts are two urban projects in flood-prone areas which were affected by the flooding of the Maine river in 1995. Flood protection requirements were integrated in these projects from the start and reinforced after the 1995 flood (Moreau, 2014). However, each project had to comply with different norms, which resulted in different urban forms, highlighting a significant shift in the scales at which flood risk was integrated into these projects.

According to the former chief architect of Angers, parking space was the number one issue raised by the Saint-Serge project. Given high flood-prone factors, it was decided not to put parking underground but to have it built on the ground floor (Figure 2). 
Figure 2 Example of an entrance to groundfloor parking and treatment of façades on the street side. Access for vehicles in the car park via a ramp. This device protects the car park and the first floor in case of flooding. Source: A. Moreau

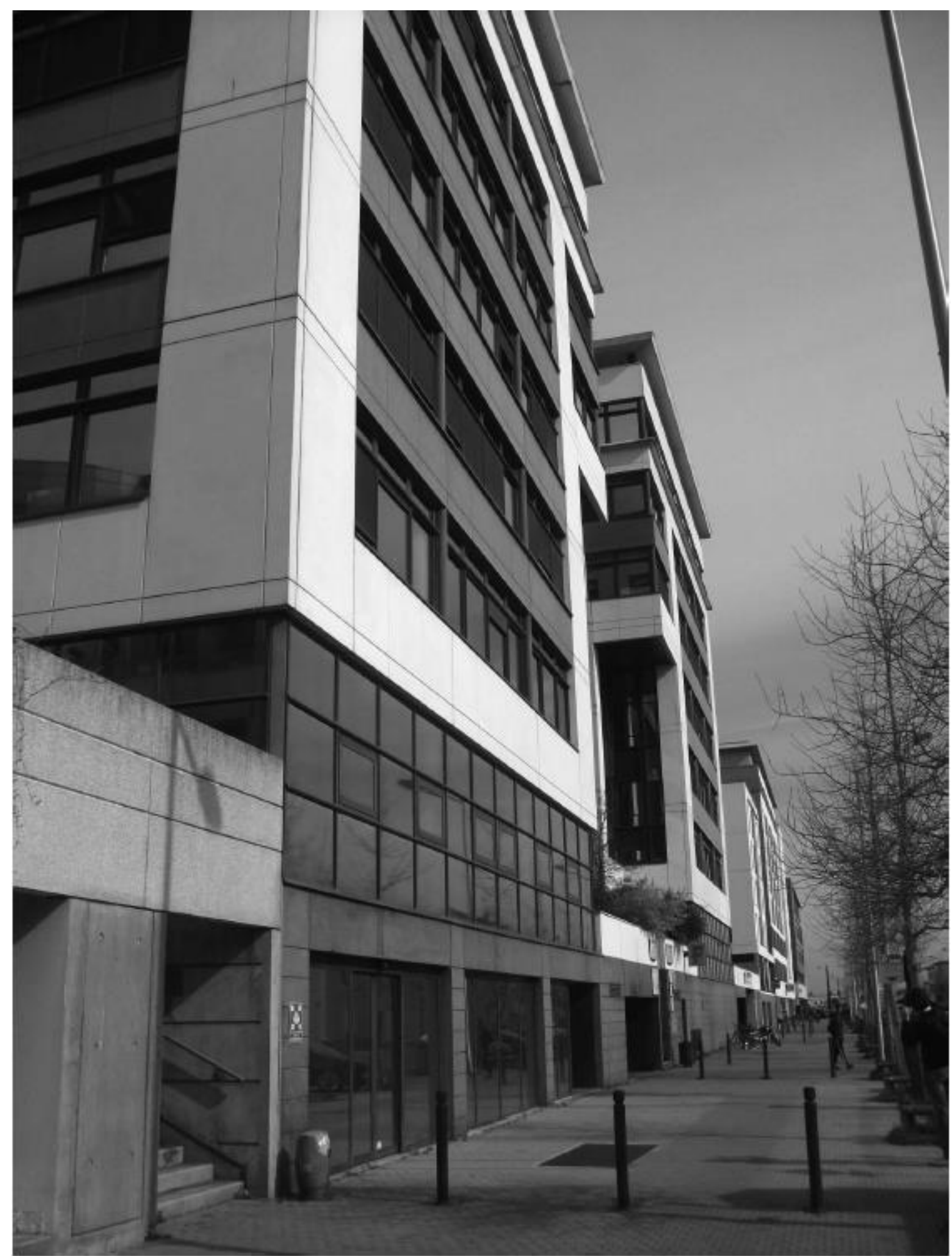

A direct result of flood constraints, this decision gives the area an urban form of its own. The slab overhanging the roadway by approximately three metres produces a kind of 'fortress street' (CretonCazanave et al., 2016, 115) with significant changes in terms of how city dwellers navigate and relate to the street (Figures 3 and 4). The area is accessible by stairways, with no direct access to the street 
from the ground floor. There is a lack of commercial facilities and, although 'lookout points' opening up a view on the city park were part of the initial plan, the height of the slab makes them hardly visible. On top of that, the highway running alongside its lower border brought about some other spatial constraints, pushing entrances to car parks and parking spaces onto the waterfront side. Combined with the overhead slab, this actually made it difficult for pedestrian traffic to develop.

From this series of technical adaptations imposed on buildings emerged some kind of island-like form sometimes described as 'brutal' when compared to its surrounding environment. Although large landscaped gardens above the public car parks are intended to create some 'breathing space', these have little effect but to reinforce the insular and extremely urban character of the neighbourhood (Figures 2 and 3 ).

Figure 3 View obstructed by the slab. The walker cannot see the urban prospects and landscaping due to the raising of the first non-floodable floor. The flood-prone car parks on the ground floor are hidden from view. Source: $A$. Moreau

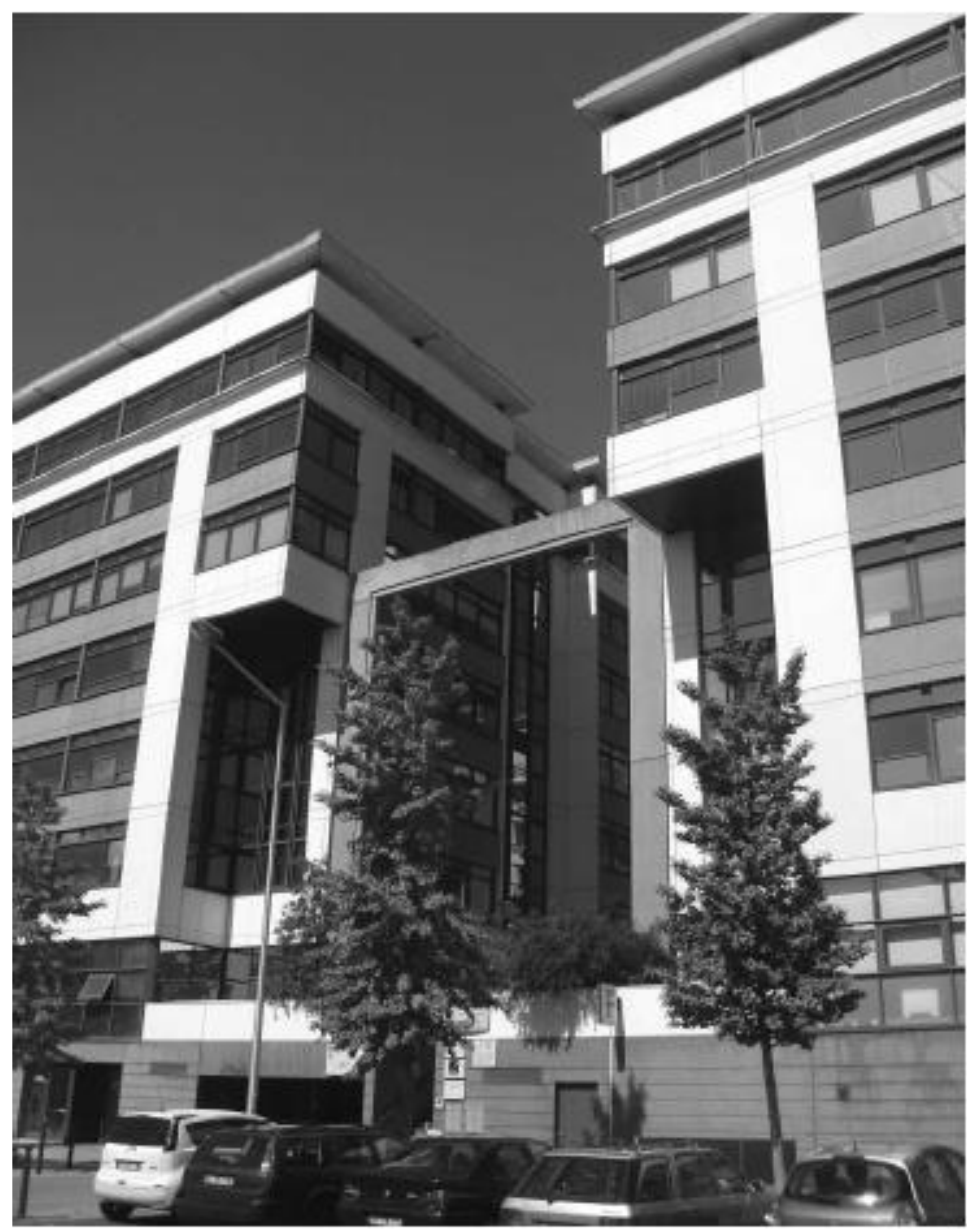


Figure 4 Row of elevated walkways. Access to buildings is difficult, especially for people with reduced mobility. The relation to the street is not direct, which raises multiple problems in terms of urban quality. Source: A. Moreau

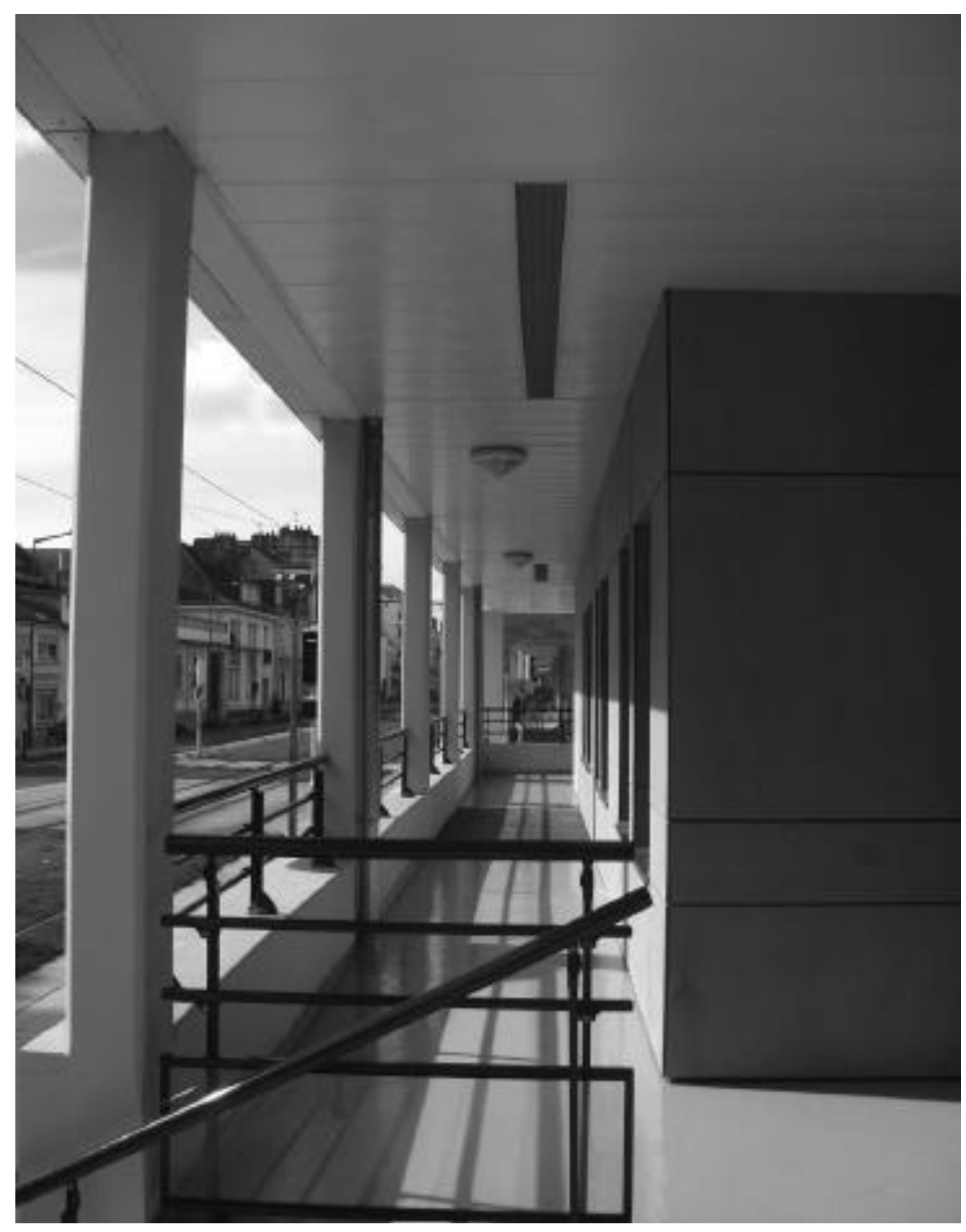

Interestingly, the Thiers Boisnet area in Angers marks a shift in terms of the scale at which flood risk was taken into account in urban development projects. Flood constraints were dealt with from the start at the area level, in an effort to let the water flow and allow the buildings to maintain their main functions during flooding times. Between 1988 and 1990, the city of Angers realised there was a need to give a new start to areas such as Saint-Serge. It initiated refurbishment plans in order to make it more residential, including the development of shops, services and parking lots. After long public consultation sessions held with NGOs and local partners, the Thiers Boisnet project was launched in April 1996, over a surface area of approximately 5.5 hectares made up of six city blocks. Municipal council decisions stipulated that 'constructions and facilities [would] integrate the constraints resulting from recent floods'. Flood risk was therefore included in the various planning documents.

When the project was launched, the whole construction sector was subject to specific provisions: habitable floors higher than PHECs, no storage of chemicals, a watertight sewer system and rapid rainfall evacuation, among others. The project was thus to integrate a minimum of fifty centimetres above PHECs for the construction of storeys in habitable spaces as well as for technical infrastructure and entries to car parks.

Building practices were thus legally framed. However, in the wake of the 1995 flood, the Thiers Boisnet project was entirely revised with the aim of 'helping people to go about their everyday activities and 
facilitate rescue operations without having to build elaborate structures' (interview with the former head architect of Angers, 29 April 2014). Town planning and architecture services defined three main orientations: a systematic elevation of buildings, the creation of walkways at the ground level and underground car parks. The area was built on a platform, block by block, with all residential levels raised by fifty centimetres above the PHECs of the 1995 flood. For buildings facing the street, it was also decided that all the ground floors would systematically include a raised arcade with entry halls, services and shops (Figure 4). All these measures were 'taken to allow people in the neighbourhood to go about their normal activities including at flood times ... We designed this neighbourhood as if the streets weren't streets but canals, like in Venice' (interview with the former head architect of Angers, 29 April 2014).

\section{Architectural responses at the block scale: mixed results}

This architectural design with covered galleries facing the street (Figure 4) is quite unusual. Walkways make it possible to walk along the buildings and one can reach the nearby block by taking a bridge over the street. However, such a systematic use of elevated structures challenges the practicability of public spaces:

Now when we go for a walk, there is this low wall, which is not necessarily a problem, even though the pedestrian walkways in between were initially designed for access to housing or professional facilities, not necessarily as a regular public space. (Interview with an architect-urbanist from AURA [Agence d'Urbanisme de la Région Angevine], 7 April 2014)

This raises a problem in terms of how city-dwellers relate to the street. The technique of elevating the first usable level generates a succession of ramps, stairways and walkways. For the city's former town planning director, it is a 'confusing structure'. The effect of combining esplanades and traffic spaces is that one cannot know whether the area is private or public. It then proves difficult to understand how to make use of elevated ground floors because they have no direct relation to the street, hence no commercial value for shopkeepers. These ambivalent results of urban shapes underline a tension between resilient flood measures and spatial quality, a problem which occurred even in the Netherlands, where the long-time dike-ring approach put spatial design practices under constraint ${ }^{5}$. According to Nillesen and Kok (2015), for a very long time all aspects of the surrounding landscape and built environment in the Netherlands had to fit protection standards set by the dike-ring approach.

As for car parks, the City of Angers and its Bureau of Architecture insisted that they should be underground and non-floodable. Indeed, the ground-level area which could endow downtown streets with a lively atmosphere should not be lost to parking spaces. All-purpose parking spaces were thus placed below the slab and buildings, mostly in tank-like underground cavities to be protected from potential water inflow.

Almost twenty years after it was launched, the project seems to have delivered mixed results. The initial plan to have shops opened on elevated ground is obviously a failure. For this neighbourhood, taking floods into account was thus

perhaps an exclusively technical response. We had to elevate the buildings, we couldn't do otherwise. Unlike the Angers rives nouvelles project, Thiers Boisnet did not benefit from any environmentally sensitive approach, as we did not take the constraints into account or consider a particular project space. Today that's what we would do. But at the time we only tried to manage water constraints. (Interview, AURA, 7 April 2014)

\footnotetext{
${ }^{5}$ The dike-ring approach refers to all the systems created in the Netherlands to protect areas from flooding, such as systems of dikes, dunes, dams, barriers and natural high ground (Nillesen and Kok, 2015).
} 
As architects/urban designers were proposing only technical responses to floods at the scale of buildings and city blocks, the whole issue was dealt with through elevation. This case study reflects an architectural approach centred on the figure of the architect/ urban designer which happened to be the prevailing model at the time.

\section{New professional specialisations for designing flood-resilient cities: a scale shift}

In an attempt to think beyond altimetric norms and land-use policies at the level of neighbourhoods, two highly specialised skills have been given priority in the way flood risks are being defined. Hydraulic engineering and landscape art know-how has now been embedded within a new approach of submersion, the role of which in urban systems and especially in landscape design has been substantially reassessed. As a matter of fact, 'relationships with water are an increasingly dominating scheme for new urban developments' (Ryan, 2010, 18; Watson and Adams, 2010).

Hydraulic modelling promotes various development principles for designing new urban areas (e.g. floodways, dredging/filling, hydraulic transparency). These aim at preparing the conditions for the water to flow freely without submerging buildings, a key element to enable urban designers and landscape designers either to proceed on to the next development stage or redraft their proposal. The commissioning of a landscape designer specialising in public spaces helps to reduce potential discrepancies between technical issues and the set of requirements pertaining to the overall urban environment. These specialisations are therefore expected to stimulate the emergence of a 'submersible' urban environment that can be considered non-vulnerable, or less vulnerable. In the eyes of urban professionals, taking flood risk into account from step one of the design phase would more or less solve the vulnerability problem. In order to be effective, this perspective shift should, of course, be integrated at the level of buildings or city blocks in compliance with existing legislation. But most importantly, it should also happen both at the area level and at the urban scale as a whole.

\section{Questioning the primacy of hydraulic modelling over urban issues}

In flood-prone areas, urban forms generated by new urban development projects have to be designed according to floodplain parameters. In compliance with PPR regulations, two hydraulic solutions are generally used at the district level for slight or moderate risk-prone areas: dredging/filling equilibrium with floodways and the hydraulic transparency principle.

In a zone under development in Narbonne, a filling was realised to raise the sector above the PHECs and limit the impact of flooding. Twenty centimetres were added above the primary level to the first storey of each new building. All the filling had to be compensated for by dredging another zone of the project. In the Matra neighbourhood in Romorantin, urban design used similar dredging techniques in some places and filling in others to produce resilient urban forms.

The design of floodways happens to be particularly challenging, to the extent that urban forms have to be adapted in order to accommodate temporary waterflows with as little damage as possible to goods and people. The Matra neighbourhood in Romorantin was, for instance, considered by its designer 'a temporary affluent of the river' (Figure 5). In this perspective, the whole urban design process must be performed in compliance with flood-risk parameters. 
Figure 5. A neighbourhood designed as a temporary affluent of the river. The buildings are oriented parallel to the river and raised on stilts so as not to obstruct the flow of water in the event of flooding. Source: EDL architect

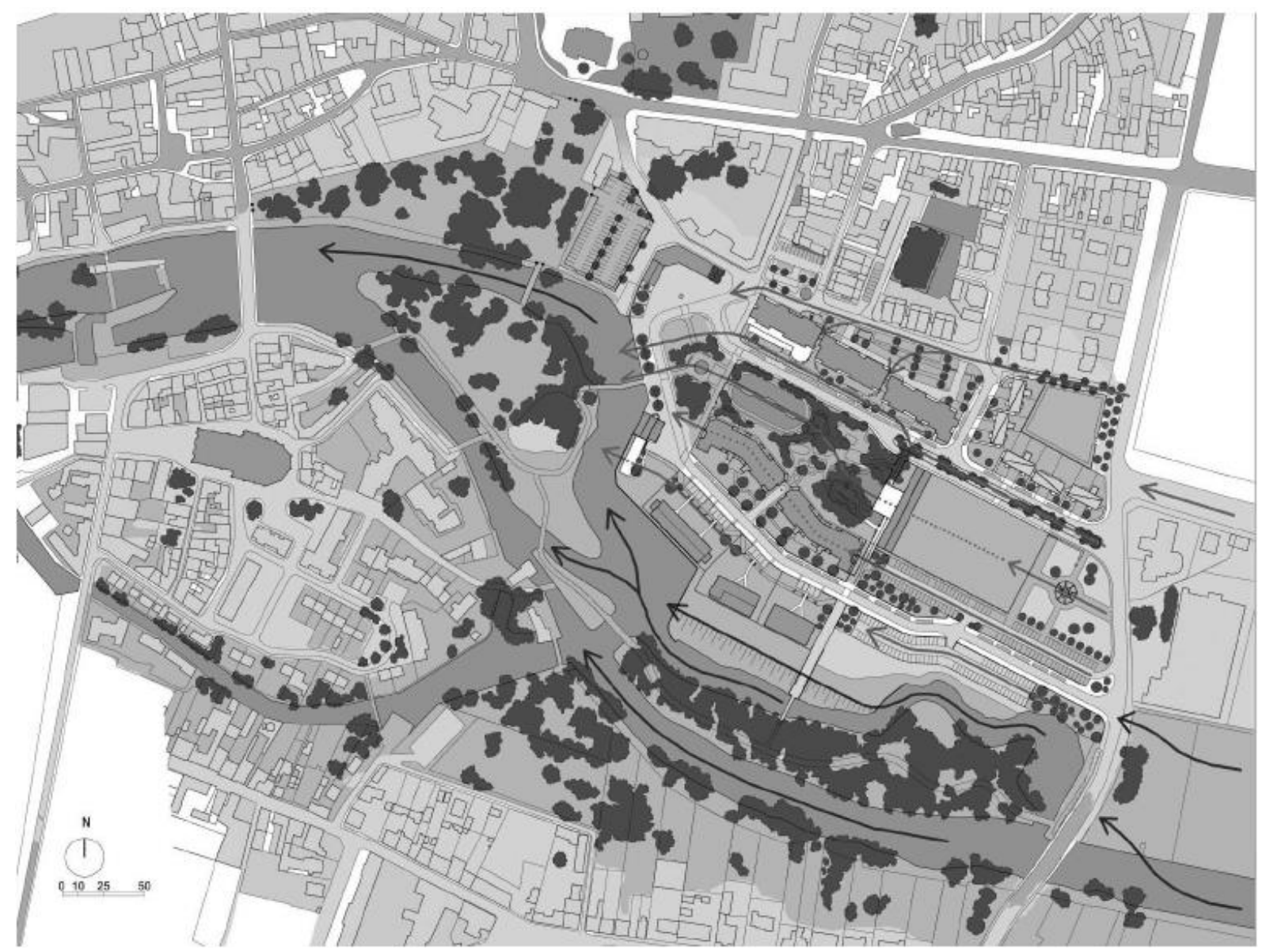

The total width of floodways must reach ninety metres over the entire development area. In the initial design, there were to be five of them, with widths varying from 7.5 to 20 metres each.

In this particular case, the architects in charge of the project selected a design approach which directly resulted from hydraulic studies undertaken by a team of specialised technical consultants. Although these floodways are expected to evolve over time in both number and width, they nonetheless appear to be one of the project's keystones, holding together its different components. With the urbanization of the northern sector of the Robine Canal, they also stand as the only effective solution to make up for the negative side effects of this new development.

A key point in this type of project among the range of options available to architects appears to be the successful integration of hydraulic modelling input.

However, in the Narbonne case, numerous evidence can be found showing the many difficulties encountered by urban designers when trying to make their choices on the basis of hydraulic input - be it in terms of city design or of lifestyle.

As a matter of fact, building pleasant and practical living spaces for residents during non-flood times appears rather difficult when hydraulic principles selected as security prerequisites turn out to be real constraints from an urban development viewpoint. A possible way out, currently under review, would 
be to reduce the number of floodways to only two or three wider units (approximately eighty metres) that would also be usable by future residents in the form of small parks with play areas. This would also create a new challenge, as it would imply finding ways for these new and larger floodways to become high-quality public spaces crystallising 'the very image of togetherness in the city' (Novarina et al., 2007). In Narbonne, the urban designer in charge of the neighbourhood summarises this ambition: 'For us, hydraulics should contribute to urban fabric' (interview, 28 September 2016). However, if what is at stake in urban design is primarily to be able to imagine in such spaces 'alternative uses for the majority of the time when they are not required to cope with flooding' (Zevenbergen, $2010,47)$, things are obviously not so simple.

\section{Articulating urban, hydraulic and landscape issues at the heart of resilient urban design}

In order to successfully reduce vulnerability and enhance resilience at the scale of a newly designed area, urban, hydraulic and landscape issues have to be articulated in a coherent manner. For this purpose, it is necessary to go beyond the current range of regulatory technical solutions, such as elevation and floodways. The key challenge is to work on city-water interfaces (for example by creating parks and gardens) in order to contribute to water landscape scenery and assert the sensible presence of water in the city.

In Narbonne, one of the main hydraulic choices that has underpinned the construction of the new neighbourhood was to create landfill on the site of pre-existing bodies of water - thus reducing water scenery to the stretch of the Robine Canal bordered by plane trees. The idea behind the proposed landscape is not, therefore, to restore the presence of water in the heart of the neighbourhood, all the more so as such water surfaces subsisting outside flood periods could also be an ominous reminder of potential hazards. Floodways - another important hydraulic principle - were also contemplated as they could increase the visibility of water and stand as a visual materialisation of potential flood risk. However, water surfaces and their floodway functions have not been included in the landscape as planned.

In the three other cities we studied, landscape design appears to be central, especially in the way it enables regeneration of city-water interfaces. In Angers, the Angers rives nouvelles project shows strong articulations between urban, water and landscape issues in what we consider on the whole a more efficient design. In this case, project designers relied on feedback provided by the Saint-Serge and Thiers Boisnet projects. These helped highlight that a technical approach such as this of elevated ground floors, despite its many advantages, raises problems in terms of views and space appropriations (interview with the director of operations, Société publique locale Angers rives nouvelles (SPL ARN), 24 March 2014).

Nowadays, architects and urban designers tend to discard this type of elevated urbanism in favour of dredging and landfill movements that help keep part of the area above water levels. Environmental issues have also become crucial in such urbanistic upgrades. In Angers, they have translated into a series of initiatives. First of all, it was decided to create a green infrastructure that would cross the city and allow a connection between the natural spaces of the Basses vallées angevines and the Loire valley. Second, an ambition was asserted to 'create the city and re-create nature in the city with its flood risks in mind. Flood risk is something we have to work with' (interview with the director of operations, SPL ARN, 24 March 2014). The idea is to find a solution that will take flooding into account. Indeed, Saint-Serge is a site of natural flood expansion as well as an extension of the city centre: flooding and urban development issues are thus particularly intertwined and should be addressed together. 
In order to do so, the choice was made to divide the space into two distinct parts while retaining numerous links between them. On the one hand, a large twenty hectare submersible park, the Parc des confluences, is to be created along the river Maine once the dredging and filling operations and the destruction of the existing roadway are completed. On top of that, a port and two islands - one kept wild and the other dedicated to an amusement park - are also to be created between the two arms of the Maine. The rest of the area will be dedicated to a more urban site. According to the project director,

the main idea ... is to keep in mind how difficult it is for human activities to be carried out under the permanent threat of flooding. However, if located alongside a natural site and inserted in a smart urban design, the same activities can continue even in the event of flooding. (Interview with the director of operations, SPL ARN, 24 March 2014)

At the same time, the reuse of dirt excavated for the creation of the park will allow the urban platform to be raised fifty-centimetre above PHECs. It should also be tapped in for a number of residential buildings and new facilities which are planned on the same sites, with the aim of reducing their overall vulnerability. The idea is to erect a non-submersible urban space, a kind of flat plateau in accordance with the principle of having ground floors directly accessible from public spaces. 'We are very much attached to the idea of a flat surface between the street and the entry to the residences, even if this means finding occasionally more complex mechanisms' (architect-urbanist, atelier Grether, 13 May 2014).

The project also plans to transform the riverbank roadway which currently isolates the Saint-Serge estate from the river Maine. The latter would be replaced by a large raised roadway running along former railtracks. This will allow the creation of the Parc des confluences and lessen inner traffic in downtown Angers. This system of raised roadways should not impede the flow of water, and the public thoroughfares, based on a grid system, would on the whole be above the PHEC. Shops and services are planned just outside residential buildings along the main avenue to ensure various services are provided and endow the neighbourhood with a city-centre spirit. In order to enlarge the riverbed and restore the natural aspects of its banks, a system of 'pleats' has been devised. With different layers and slopes ensuring run-of-the-river accessibility in all seasons, the latter can be appropriated in different ways in terms of use and vegetation. This system complies with the specificities of the Maine, whose hydraulic regime is characterised by a large tidal range. It also aims at granting the river more room for flooding. The dredging and filling process carried out prior to construction by means of the pleat system will, when combined with the landscaping of the riverbank, reinforce the sense of water in the neighbourhood.

Even though parts of the Rives nouvelles project, such as the Parc des confluences, have been dropped after a change in the political majority at city council elections, the (new) Angers Coeur de Maine project has taken over some of the old project's objectives, such as reconnecting the city to its waterway through various planning projects, the historic centre remaining the priority area to develop. This approach calls to mind projects developed in other countries, such as the Yolo Bypass for Sacramento river in the United States, 'the Room for the river' project in the Netherlands, or the 'making space for water' policy in England (Moss and Monstadt, 2008; Opperman et al., 2009; Nillesen and Kok, 2015; Liao, 2012). Even though many of them meet a number of institutional and operational difficulties, these different restoration projects brought together help us see a clear global trend shaping up (Moss and Monstadt, 2008).

In the district of Saint-Nicolas, in Le Havre, the buildings have similarily been raised and the city-water interface regenerated with the design of a jardin fluvial along the fluvial basin. In Romorantin too, 
landscape design turns out to play a key role in this resilience-oriented project. For example, a famous landscape designer who had 'skills in landscape designing but also in flood management' got on board and worked out the project along with its chief architect (interview with the architect in charge of the Matra project, 26 May 2016). The latter firmly believes that the landscape design of public spaces can, beyond technical solutions, contribute to evoking the presence of water and the risk of flooding at both concrete and symbolic levels.

In our opinion, the resilience of neighbourhoods developed in flood-prone areas should only be assessed according to the two following criteria: keeping residential buildings out of the water thanks to a combination of technical solutions, and encouraging risk awareness by resorting to the visible presence of water.

\section{Conclusion}

Many urban development projects are under way in flood-prone areas. For decision makers, the strategic position of floodplain spaces and their potential for innovation seem to outweigh the many operational constraints they can incur. However, such constraints are interpreted in multiple ways by planning professionals. Urban development projects make use of an array of technical means (hydraulics, engineering, architecture) (Barroca and Serre, 2012; Barroca and Hubert, 2008) to create a city life 'that goes on despite the flood' (Lesquel, 2012, 30). In general, three main solutions are implemented to integrate flood risk into urban development projects: the raising of buildings or grounds to place them above water level, the creation of floodways to ensure the free flow of water, and finally the regeneration of city-water interfaces in the form of water landscapes which reinforce the sensitive presence of water in the city (Rode and Gralepois, 2017).

Taking flood risk into account from the very start of urban projects sometimes affects relationships between local authorities, urban project professionals and state services. Rules have to be negotiated and adapted on a case-by-case basis while remaining in tune with the general requirements of flood risk prevention.

The urban projects we studied show a shift in scale that has been brought about by the integration of flood risks. Priority has moved from the specific scale of the building to the wider scale of the area, where urban forms are designed to be less vulnerable. This requires the coordinated intervention of numerous professionals - architects/ urban designers, hydraulic engineers and landscape designers. This emergence in urban project design of professionals who were previously confined to more circumscribed technical interventions puts into question the central role of the architect/ urban designer. Such devolution dynamics allow projects to tackle issues of vulnerability and resilience in flood-prone urban spaces from the broader point of view of urban morphology, marking a break from a former and narrower approach which tended to focus on buildings' compliance with regulatory specifications.

If we look at other countries, we can see that many cities have adopted technical and urban design measures after they were hit by extreme events, bringing, for example, significant changes in their building codes. After Hurricane Sandy, the city of New York not only compelled building owners to take out flood-risk insurance, but also incorporated flood-resistant provisions into construction standards. For instance, a design flood elevation (DFE) was defined under which living areas are not permitted, making it only possible for parking, access and storage spaces to be built (City of New York, 2013). However, discussion on resilience remains very restrictive when it appears to be limited to technical points and flood-prone areas. In Germany, a series of floodsin 2002 and 2013 showed that technical 
and construction measures are no longer effective when exceptional events occur (Otto et al., 2016). Measures of this kind can generate a feeling of security but also contribute to minimising risk awareness. Implementing them can turn out to be rather complex and bring about a number of conflicts. For example, they can be rejected by proponents of nature conservation (Otto et al., 2016).

Taking a step back, we can thus see urban resilience as being a matter of urban design. But it should not be limited to this. Indeed, it also stands as a matter of territorial planning on scales larger than that of the neighbourhood. The resilient organization of a territory should be thought out at a regional or an urban level. At the same time, crisis management should be central and its integration into the development process anticipated every time new urban developments are to be implemented in floodprone areas. When major flood events cause disruption over large territories, organizational and logistic aspects of crisis management should not be neglected, as is often the case, neither should issues of scales be overlooked. In many regards, contemporary cities appear as 'agglomerations existing in a just-in-time framework' (Gralepois, 2010, 64). Blockages are often a major risk, putting at threat the functioning of urban systems as a whole. However, resilience could be significantly enhanced by being articulated at different scales simultaneously. In the cases we studied, this articulation proved difficult to implement. Urban professionals find it difficult to reconcile the problem of risks with of city living, which is already a major stake for urban design (Rode and Gralepois, 2017). Nonetheless, the integration of risks from the very start of project design and planning phases should gradually lead to positive evolution in these practices.

\section{References}

ALLAMAN, M. (2003), 'L'odyssée des villes et de leur fleuve', Diagonal, 163, 22-25.

ANTROBUS, D. (2010), 'The importance of the "not-so-cool" sectors: creative solutions to reconcile environmental and economic sustainability within a floodplain', Local Environment, 15, 295-308, http://dx.doi.org/10.2307/951696 (accessed 25 June 2017).

ARAB, N. (2007), 'Activité de projet et aménagement urbain: les sciences de gestion à l'épreuve de I'urbanisme', Management \& Avenir, 12, 147-64, http://www.cairn.info/revue-management-etavenir-2007-2-page-147.htm (accessed 24 June 2014).

ATELIER CASTRO DENISSOF CASI and NEXITY (2011), Vivre le fleuve: les chemins de l'urbanité, Nexity, Paris, http://asset.rue89.com/files/Vivre_le_fleuve.pdf (accessed 28 May 2015).

BARROCA, B. and HUBERT, G. (2008), 'Urbaniser les zones inondables, est-ce concevable?', Développement durable et territoires, http://developpementdurable.revues.org/7413 (accessed 14 June 2014).

BARROCA, B. and SERRE, D. (2012), 'De la ville qui sépare à la ville qui intègre', Travaux, 886, 32-35.

BEUCHER, S. and RODE, S. (2009), 'L'aménagement des territoires face au risque d'inondation: Regards croisés sur la Loire moyenne et le Val-de-Marne', M@ppemonde, 94, http://mappemonde.mgm.fr/num22/articles/art09202.html (accessed 16 October 2016).

BEURIER, E. (2011), 'Etendre la ville aux zones inondables?', Le moniteur des travaux publics et du bâtiment, 5613, 34-37.

BONNET, F. (2016), Atout risques, des territoires exposés se réinventent, Marseille, Parenthèse. 
CARRE, C. (2006), 'Les évolutions en France dans la théorie et les pratiques d'une gestion territoriale du risque : L'application au cas des inondations', Annales de géographie, 648, 133-53.

CITY OF NEW YORK (2013), PlaNYC: A Stronger and More Resilient New York (New York City), http://www.nyc.gov/html/sirr/html/report/report.shtml (accessed 21 June 2017).

COMMISSARIAT GENERAL AU DEVELOPPEMENT DURABLE (2009), Croissance du nombre de logements en zones inondables, Le point sur, 6, MEDDE, http://www.developpementdurable.gouv.fr/IMG/spipwwwmedad/pdf/LePointSur_N6_cle03d2dd.pd $f$ (accessed 20 September 2014).

COMMISSARIAT GENERAL AU DEVELOPPEMENT DURABLE (2010), L'environnement en France. Édition 2010 (Ministère de l'écologie, de l'énergie, du développement durable et de la mer), http://www.statistiques.developpement-durable.gouv.fr (accessed 10 September 2014).

CRETON-CAZANAVE, L., DEROUBAIX, J.-F., HUBERT, G., DUBOIS-MAURY, J. and NOVEMBER, V. (2016) 'Un "urbanisme résilient" en zone inondable : Le cas des Ardoines, en région Parisienne', in F. Rudolf (ed.), Les villes à la croisée des stratégies globales et locales des enjeux climatiques, Quebec, Presses de l'Université Laval, 101-31.

DEGARDIN, F. (2002), 'Urbanisation et inondations : De l'opposition à la réconciliation', Bulletin de I'Association des géographes français, 1, 91-103.

DEGARDIN, F. and GAIDE, P. A. (1999), Valoriser les zones inondables dans l'aménagement urbain, LyOn, CERTU.

DEMAZIERE, C. (2014), 'Pourquoi et comment analyser les villes moyennes ? Un potentiel pour la recherche urbaine', Métropolitiques, http://www.metropolitiques.eu/Pourquoi-etcommentanalyser-les.html (accessed 13 October 2014).

GAUDILLIERE, J.-P. (2005), 'Pour une ville durable: Entretien avec Cyria Emelianoff', Mouvements, 41, $57-63$.

GRALEPOIS, M. (2010), 'L'agglomération à flux tendus: La politique de sécurité civile française au secours des pannes de réseaux', Flux, 81, 57-66.

HUBERT, G. (2014), 'The city and flooding: an uneasy cohabitation', in J.-J. Terrin (ed.), Cities and Flooding, Marseille, Parenthèses, 220-30.

INGALLINA, P. (2008), Le projet urbain, 4th edn, Paris, P.U.F.

LARROUY-CASTERA, X. and OURLIAC, J.-P. (2004), Risques et urbanisme: Risques naturels, risques technologiques - prévention - responsabilités, Paris, Editions du Moniteur.

LECHNER, G. (2006), Le fleuve dans la ville. La valorisation des berges en milieu urbain, Paris-La Défense, Direction générale de l'urbanisme, de l'habitat et de la construction, 120, http://www.cdu.urbanisme.developpement-

durable.gouv.fr/IMG/pdf/fleuvedanslavilleaveccouv_cle24aafe.pdf (accessed 28 May 2015).

LESQUEL, E. (2010), 'Risques technologiques et naturels: Comment enfin les prévenir?', Courrier des maires et des élus locaux, 241, 18-25.

LESQUEL, E. (2012), 'Construire en zone inondable sans boire la tasse', La gazette des communes, 2127, 30-32. 
LIAO, K. (2012), 'A theory on urban resilience to floods: a basis for alternative planning practices', Ecology and Society, 4, http://dx.doi.org/10.5751/ES-05231-170448 (accessed 20 June 2017).

MARIE, J.-B. (2014), 'Risk-integrated urban planning in Hamburg', in Terrin (ed.), 94-104.

MOREAU, A. (2014), Intégration du risque d'inondation dans les projets urbains en zone inondable: étude de cas à Angers, Engineer Degree's Dissertation, Topography and land surveying speciality (dir. Mathieu Bonnefond), CNAM, Le Mans.

MOSS, T. and MONSTADT, J. (eds) (2008), Restoring Floodplains in Europe: Policy Contexts and Project Experiences, London, IWA Publishing.

MOULIN, E., DEROUBAIX, J.-F. and HUBERT, G. (2013), 'La constructibilité des zones inondables ou la négociation territoriale de la règle', Géocarrefour, 3, 173-82.

NADOU, F. (2010), 'La notion de "villes intermédiaires": une approche différenciée du rôle des villes moyennes: entre une structuration territoriale et spécificités socio-économiques', https://halshs.archives-ouvertes.fr/halshs-00596204/PDF/Article_Final.pdf (accessed 28 May 2015).

NILLESEN, A. L. and KOK, M. (2015), 'An integrated approach to flood risk management and spatial quality for a Netherlands river polder area', Mitigation and Adaptation Strategies for Global Change, 6, 949-66.

NOVARINA, G. (2003), Plan et projet: L'urbanisme en France et en Italie, Paris, Anthropos.

NOVARINA, G., AMBROSINO, C., COGATO-LANZA, E., ROUX, J.-M., SADOUX, S., SEIGNEURET, N. and VAYSSIERE, B. (2007), Projets urbains en Europe (Rapport de recherche pour le PUCA), Grenoble.

OPPERMAN, J. J., GALLOWAY, G. E., FARGIONE, J., MOUNT, J. F., RICHTER, B. D., and SECCHI, S. (2009), 'Sustainable floodplains through large-scale reconnection to rivers', Science, 326,1487-88, http://dx.doi.org/10.1126/science.1178256 (accessed 20 June 2017).

OTTO, A., HORNBERG, A. and THIEKEN, A. H. (2016), 'Local controversies of flood risk reduction measures in Germany: an explorative overview and recent insights', Journal of Flood Risk Management, http://dx.doi.org/10.1111/jfr3.12227 (accessed 29 June 2017).

PIEL, C. (2014), 'Hydrology and urban projects', in Terrin (ed.), 236-46.

PIGEON, P. (2007), 'Les plans de prévention des risques (PPR): essai d'interprétation géographique', Géocarrefour, 1-2, 27-34.

RODE, S. (2009), Au risque du fleuve : La territorialisation de la politique de prévention du risque $d^{\prime}$ inondation en Loire moyenne (doctoral thesis in geography), Paris, Université Paris Ouest Nanterre La Défense, http://tel.archives-ouvertes.fr/tel-00444166/fr (accessed 15 October 2016).

RODE, S. (2012), 'Le chêne ou le roseau: Quelles stratégies de gestion du risque d'inondation en France?', Cybergeo: European Journal of Geography (online), Aménagement, Urbanisme, document 603, http://cybergeo.revues.org/25299 (accessed 15 October 2016).

RODE, S. and GRALEPOIS, M. (2017), 'Towards an urban design adapted to flood risk?', in F. Vinet (ed.), Floods. Volume 2: Risk Management, ISTE Press, Elsevier, 365-78.

RYAN, Z. (ed.) (2010), Building with Water: Concepts, Typology, Design, Basel, Birkhäuser. 
VAN VEELEN, P. C. (2016), Adaptive Planning for Resilient Coastal Waterfronts: Linking Flood Risk Reduction with Urban Development in Rotterdam and New York City, Delft, Technische Universiteit Delft, Faculty of Architecture and the Built Environment, Department of Urbanism.

VERDELLI, L. and MORUCCI, F. (2014), 'Renouveler l'identité de la ville entre culture portuaire et loisirs', Loisir et société, 1, 58-78.

WATSON, D. and ADAMS, M. (2010), Design for Flooding: Architecture, Landscape, and Urban Design for Resilience to Climate Change, Hoboken, NY, Wiley.

WEBLER, H. (2014), 'A multi-stakeholder strategy for the Zollhafen project, Mainz', in Terrin (ed.), 11022.

ZEVENBERGEN, C. (2010), 'Towards flood-resilient urban environments', in Ryan (ed.), 41-49.

\section{About the authors}

Sylvain Rode is Assistant Professor in Urban and Regional Planning at Université de Perpignan Via Domitia, 52 avenue Paul Alduy, Perpignan F-66860, France;

Sofia Guevara is a PhD Candidate at Université Paris-Est Creteil Val de Marne, 61 avenue du Général de Gaulle, Creteil, île-de-France 94010, France;

Mathieu Bonnefond is Assistant Professor in Urban and Regional Planning at the Ecole supérieure des géomètres et topographes, 1 boulevard Pythagore, 72000 Le Mans, France; email: sylvain.rode@univperp.fr; guevi.sofia@gmail.com; mathieu.bonnefond@cnam.fr 